\title{
RH一脱ガス装置による取鍋精錬技術
}

小舞 忠信*.水上 義正* ·伊賀 …幸*
楠 隆* 鈴木 真*

\section{New Application of RH Degassing Technology in Ladle Metallurgy}

\author{
Tadanobu Komar, Yoshimasa Mrzukami, Kazuyuki IGa \\ Takashi Kusunokr, and Shin SuzukI
}

\begin{abstract}
Synopsis :
A new process has been developed as a result of $\mathrm{R} \& \mathrm{D}$ effort to investigate and establish the feasibility of applying degassing technology to the molten steel to produce steels with low concentration of phosphorus, sulphur, oxygen and hydrogen.

The VOF process (namely Vacuum-Oxygen-Flux Process) consists basically of the following steps; (1) desulphurization during tapping of molten steel from an LD converter, (2) transferring the desulphurized liquid steel to a ladle during which slag is removed from the molten bath, (3) heating the molten steel in the RH vessel, (4) adding the flux of 1:1 mixture of lime and fluorite into an RH vacuum vessel for further desulphurization, degassing and deoxidation of the molten steel.

The new development has made it possible to reduce the sulphur content of steel down to approximately 0.002 percent, phosphorus content to 0.015 percent, oxygen content to 0.002 percent and hydrogen content to 0.00015 percent.
\end{abstract}

\section{1. 緒言}

科学技術の進歩とともに，鋼忉の施工力法之使用環境 は多様化しているため, 鋼材にも滈度な品質特性が望求 されるようになつた。特に, 海洋構造物用・化器:工業容 器用厚板材あるいは耐サワーガス用ラインパイン材など において, この要求を満たすためには, 鋼中の $\mathrm{P}, \mathrm{S}, \mathrm{O}$ および H などの不純物元素を闹時に低卜ささせた清浄鋼 を溶製することが必須条件となっている11.

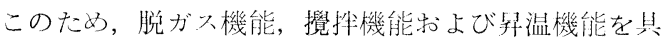
備したVAD 法2)，ASEA-SKF 法33 などの取鍋精錬法 が開発され，清浄鋼の製造に大きく简少している。しか し, これらの方法では生滻性が悪く, 設備費および操業 費が高くなるなどの欠点がある4)

上記方法の欠点を改善与るために，現状の $\mathrm{RH}$ 機能 に更に梨温機能々脱硫機能を付加し，安洒に清浮鋼が製 造できるプロセス（以後 VOF 法, 一Vacuum Oxygen Flux一と称す）を開発したので瞃告する.

\section{2. 実 験 方 法}

\section{$2 \cdot 1$ 実機 RH における昇温実験}

$\mathrm{RH}$ 真空槽内の溶鋼に $\mathrm{O}_{2}$ ガス吹き込及，溶鋼中の $\mathrm{Al}$ 酸化させる昇温う法において，溶鋼温度，溶鋼成
分および介在物の挙動を調べるたるに, $160 \mathrm{t}$ RH定用い

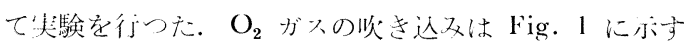

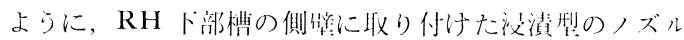
から行い，更にノズル汾刘のために $\Lambda \mathrm{r}$ ガ火などの仡 活性力゙劣间㭙に吹き这九でいる。（以後 RH・OB-FD 法,一RH Oxygen Blowing-Full Dip一飞称与) また,

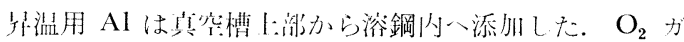

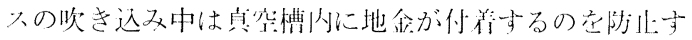
るたひに，南究度を 50〜100 Torr に制御し，RH・OB-

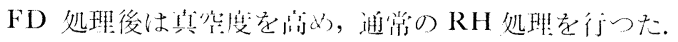

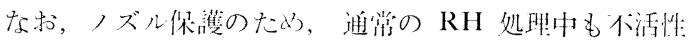
ガスを吹き込みながら脱が火处理を行つており，環流速 度は約 $25 \sim 30 \mathrm{t} / \mathrm{min}$ で西㞋. RH.OB-FI) 処理時㧍上 びての後の通常 $\mathrm{RH}$ 処理時に適け，澌温上内栙 $15 \mathrm{~mm}$ の不英管による溶鋼陚料採收を行い，浴鋼の温度、成分 拉よび介在物の組成変化について調湘した。

\section{$2 \cdot 2$ タンマン炉による脱硫実験}

SM50A (C: $0.15 \mathrm{wt} \%$, Si : $0.25 \mathrm{wt} \%, \quad M n: 1.45$ $\mathrm{wt} \%$ ）の鋼 $500 \mathrm{~g}$ をタンーン昫で溶解し， $1600^{\circ} \mathrm{C} て ゙$ $15 \mathrm{~min}$ 保持した後，「Al]が $0.020 \mathrm{wt} \%$ になる上うに アルミニウムそ添加したここの時の [T.O] は 0.006 0.009 wt\% であつた。艺の後、酸化カルシウ々 $(\mathrm{CaO})$ に 20 80 wt\% の弗化力ルシウら $\left(\mathrm{CaF}_{2}\right)$ を含有した 


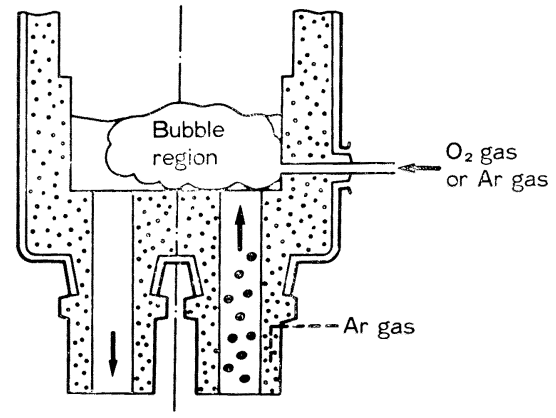

Fig. 1. Schematic expression of oxygen blowing nozzles in the RH.OB-FD.

萛本入ラグにアルミナ $\left(\mathrm{Al}_{2} \mathrm{O}_{3}\right)$, シリカ $\left(\mathrm{SiO}_{2}\right)$, 転炉

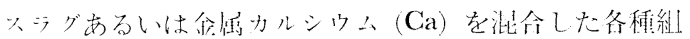

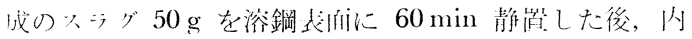

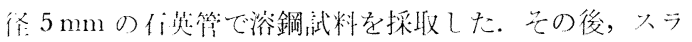

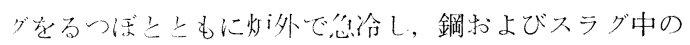

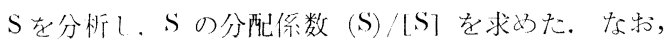

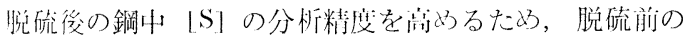

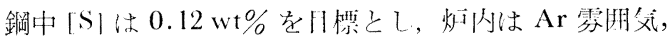

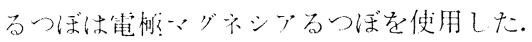

また，スラグの静济時间については，各基本スラグに

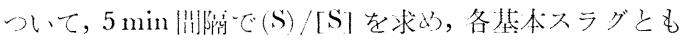

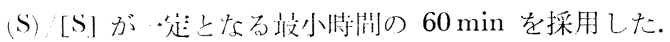

\section{$2 \cdot 3$ 実機 RH における脱硫実験}

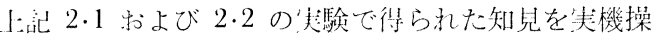

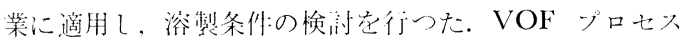
はFig. 2 および Table 1 に亦したように, $160 \mathrm{t}$ 転炉 で吹鍊した浴鋼を２鍋出鋼によりメラグカットした後， RH.OB-FD 法にて少温した。 その後, RH 真空槽内に 脱硫用スラグを添加し，溶鋼の脱硫脱酸笑験を行つた。 その後は通管の RH 処理による脱ガ火と合金添加によ る成分調整を行つた。な找用した脱硫用スラグは生

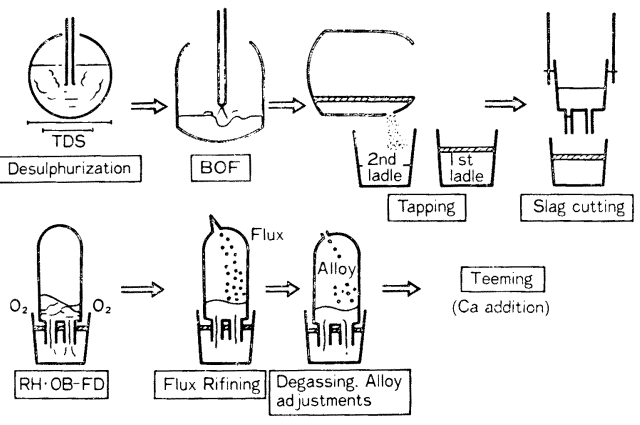

Fig. 2. Processing steps for producing clean steel by the VOF process.
Table 1. Refining steps of the VOF process.

\begin{tabular}{|c|c|}
\hline Steps & Treatment \\
\hline $\begin{array}{l}\text { Desuiphurization } \\
\text { of hot metal }\end{array}$ & $250 \mathrm{O} /$ heat $\left(\mathrm{CaC}_{2}\right.$ in jection in the torpedo vessel) \\
\hline $\mathrm{BOF}$ & $0160 \mathrm{t} /$ heat(burnt lime: $80 \mathrm{~kg} / \mathrm{t}$-steel) \\
\hline $\begin{array}{l}\text { Tapping and } \\
\text { slag cutting }\end{array}$ & $\begin{array}{l}\text { I st tapping into Ist ladle } 120 t \text { deoxidized with } \\
\text { aluminium and silicon. } \\
\text { 2nd tapping into 2nd ladle about } 40 \mathrm{t} \text {. undeoxidized. } \\
\text { Reladling from 2nd ladle into I st ladle. }\end{array}$ \\
\hline $\mathrm{RH} \cdot \mathrm{OB}-\mathrm{FD}$ & - Temperature ad justment by oxygen blowing. \\
\hline Flux refining & fluxes addition $\left(50 \% \mathrm{CaO}-50 \% \mathrm{CaF}_{2}\right)$ \\
\hline $\begin{array}{l}\text { Degassing and } \\
\text { alloy addition }\end{array}$ & ordinary method \\
\hline Teeming & $\mathrm{Ca}$ addition with wire feeding \\
\hline
\end{tabular}

不庅々螢石者重早比で 1 対 1 に混合したものであり，溶 製鋼秏は海洋椿造物用・液化天然ガス容器用厚板材ある いは耐サワーガ久用ラインパイプ材などの $\mathrm{Al} \cdot \mathrm{Si}$ キル ド鋼である。

\section{3. 実 験 結 果}

\section{$3 \cdot 1$ 実機 RH における昇温実験結果}

Fig. 3 に $160 \mathrm{t}$ の溶鋼を送酸速度 $1100 \mathrm{Nm}^{3} / \mathrm{h}$ で $\mathrm{RH} \cdot \mathrm{OB}-\mathrm{FD}$ 処理を行つた時の溶鋼の温度変化を示す. 闵中タイプ Aは通常 $\mathrm{RH}$ 処理時の溶鋼の温度降下を示 す. タイプ Bは针温用の $\mathrm{Al}$ を $1.7 \mathrm{~kg} / \mathrm{t}$ 使用し, 約 20 min 送酸した場合で，RH 処理中の温度降下を補償する ことにより，転炉の负荷軽減と低温出鋼による脱燐率の 向上をはかつたものである。また，タイプCは昇温用の $\mathrm{Al} 4.0 \mathrm{~kg} / \mathrm{t}$ 使用し, 約 $40 \mathrm{~min}$ 送酸した場合で, 約 $100^{\circ} \mathrm{C}$ の年韲ができ，後述する2 鍋出鋼による転炉久ラ グのカットおよび真空槽内への脱硫用スラグの添加など

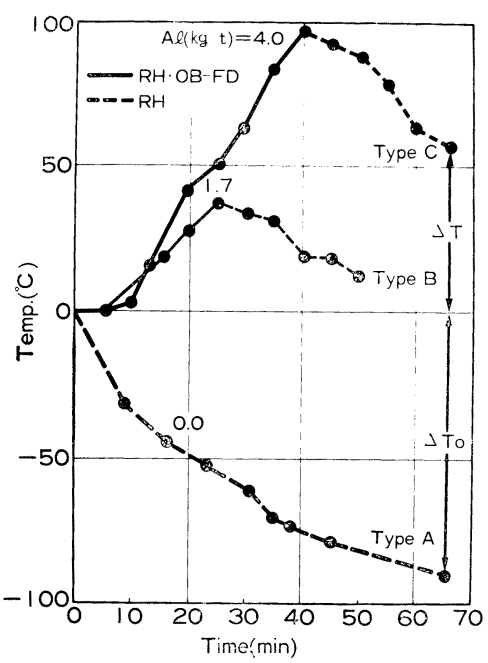

Fig. 3. Behavior of temperature in the $\mathrm{RH} \cdot \mathrm{OB}-\mathrm{FD}$. 
の治金操作孞可能となつた。

このよらな昇温方法において開題となるのは，溶鋼の 成分変動と介在物の浮上である. Fig. 4 Fig. 7 に RH. $\mathrm{OB}-\mathrm{FI})$ 処理時の溶鋼中の $[\mathrm{A} 1]<[\mathrm{C}], \mid \mathrm{Si}],[\mathrm{Mn}]$

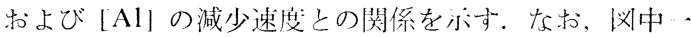
点鎖線は平均值で，破線はばらつきの籁井を小卞。[Al] か $0.050 \mathrm{wt} \%$ 以上存在吉る場合は [Al] か傻先酸化さ れ，脱炭は淘とんど生じないが，[A1] が減少するに一， れて脱炭は速くなり, 送酸速度か $1100 \mathrm{Nm}^{3} / \mathrm{h}$ の場合, 脱炭速度は化学量部的に求支る $0.01 \mathrm{wt} \% / \mathrm{min}$ に近つ く、脱珪および脱マンガン速度については，[A1]の影 響は小さいが，[Al] が増加するにつれて，速度が減少 する傾向がみられる・また，脱アルミニウム速度は [Al] が $0.100 \mathrm{wt} \%$ 以上になるとほぼ一定の速度となるが， 逆に [Al] が $0.050 \mathrm{wt} \%$ 以下になると急激に低卜歹る。 以上のごとく, RH·OB-FD 処理中の溶鋼成分の変動は

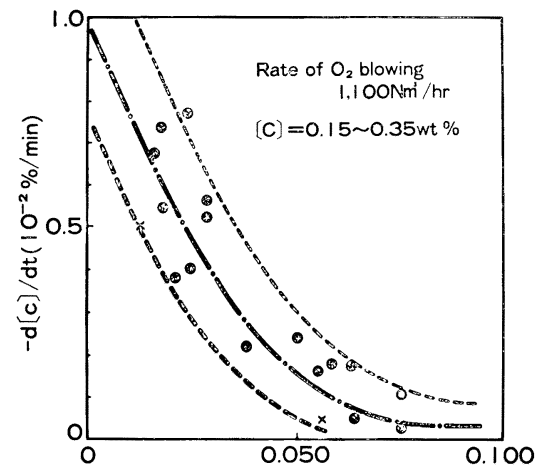

(Al) in the RH.OB-FD(wt \%)

Fig. 4. Relation between $[\mathrm{Al}]$ and $-\frac{d[\mathrm{C}]}{d t}$ in the RH.OB-FD.

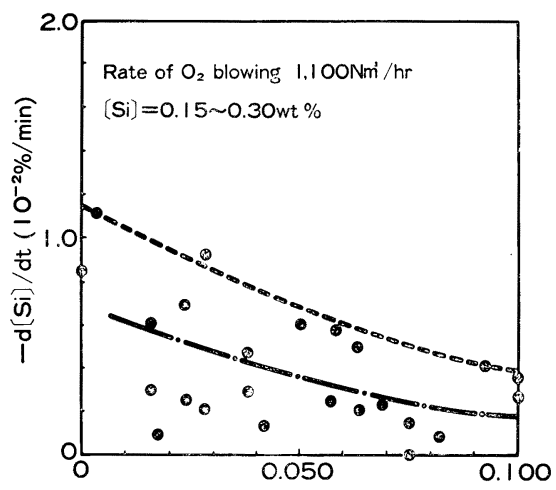

(Al) in the RH.OB-FD (wt \%)

Fig. 5. Relation between $[\mathrm{Al}]$ and $-\frac{d[\mathrm{Si}]}{d t}$ in the $\mathrm{RH} \cdot \mathrm{OB}-\mathrm{FD}$.

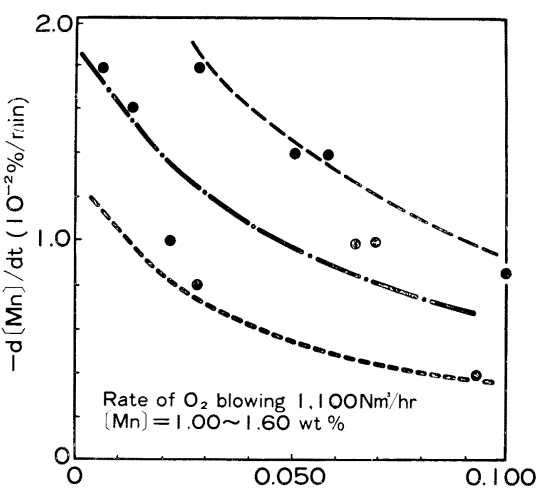

( $\mathrm{Al}$ ] in the $\mathrm{RH} \cdot \mathrm{OB}-\mathrm{FD}$ (wt \%)

Fig. 6. Relation between $[\mathrm{Al}]$ and $-d[\mathrm{Mn}]$ in the $\mathrm{RH} \cdot \mathrm{OB}-\mathrm{FH}$.

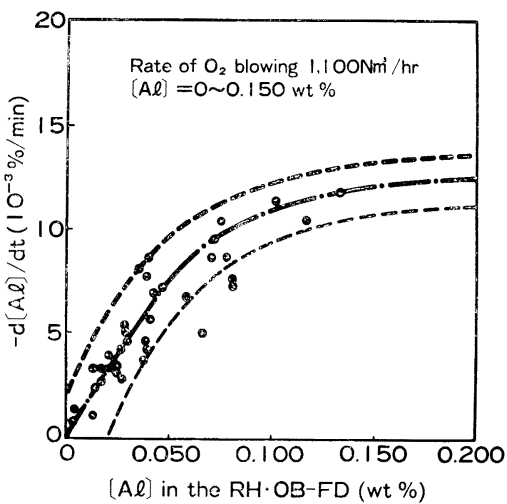

Fig. 7. Relation between $[\mathrm{Al}]$ and $d[\mathrm{Al}]$ in the RH.OB-Fl).

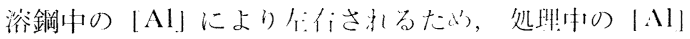

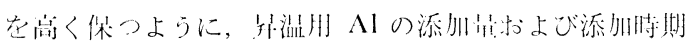
を管理する必装がある。

Fig. 8 に RH.OB-FI) 終了诗点(以降 $\mathrm{OB}_{\mathrm{E}}$ 上称一)

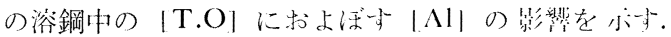
[T.O] は 50〜300 ppm の籁明にあるが，|Al」を $\mathrm{OB}_{\mathrm{E}}$ で $0.050 \mathrm{wt} \%$ 以は:保てば，T.O」を60 ppm 以上に

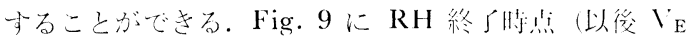
と称す)の [T.O]に求よばす RH・OB-FI) 後の RH

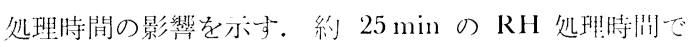
[T.O]は $30 \mathrm{ppm}$ 以下に低卜しておら， RH.OB-FD

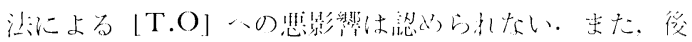

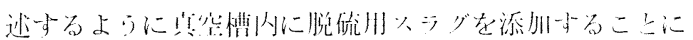
より，史に〔T.O」を下げることも㞴能である。 RH・ $\mathrm{OB}-\mathrm{FD}$ 処理中拉よびその後の通常 $\mathrm{RH}$ 処理中の介在

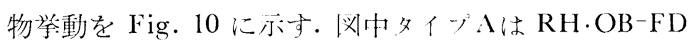




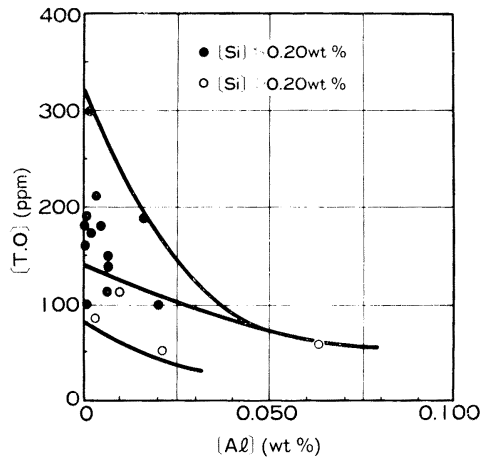

Fig. 8. Relation between [Al] and [T.O] at the $\mathrm{OB}_{\mathrm{E}}$.

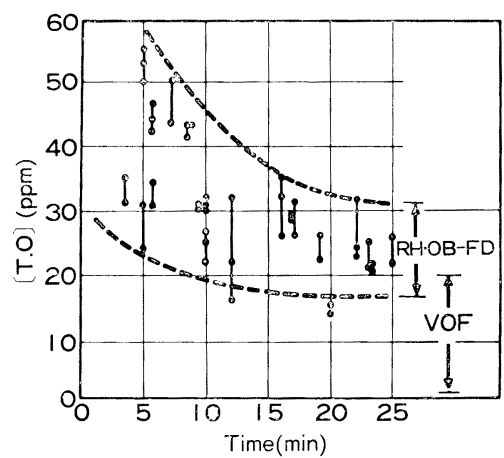

Fig. 9. Relation between time after $\mathrm{Al}$ addition and [T.O] at $\mathrm{RH}_{\mathrm{E}}$.

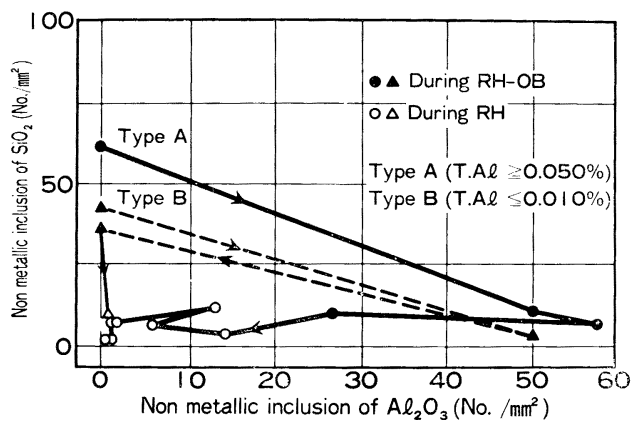

Fig. 10. Behavior of non metallic inclusions in liquid steel in the oxygen blowing and refining steps.

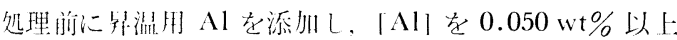

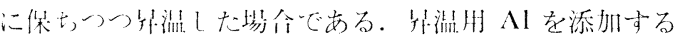

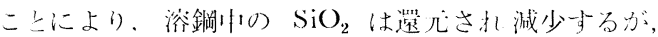

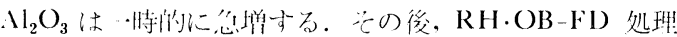

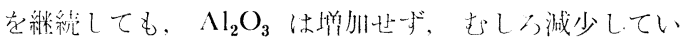
る. …j, タイ

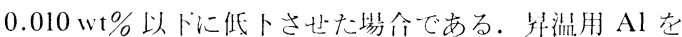

添加した時点ではタイプ $\mathrm{A}$ の場合と同様， $\mathrm{Si}_{2} \mathrm{O}$ は減少 L $\mathrm{Al}_{2} \mathrm{O}_{3}$ が増加与るが，更に RH.OB-FD 処理を継続 すると [Si] が再酸化され， $\mathrm{Al}$ 添加前と同じ水準まで $\mathrm{SiO}_{2}$ が増加する。この $\mathrm{SiO}_{2}$ はその後の $\mathrm{RH}$ 処理によ 门減少するが，タイプ $\mathrm{A}$ と比較して、 $\mathrm{V}_{\mathrm{E}}$ での $\mathrm{SiO}_{2}$ は 若ナ多くなつている。

以上の結果より，RH・OB-FD 処理中の溶鋼成分の変 動防止执よび介在物の減少をはかるためには，[Al] を $0.050 \mathrm{wt} \%$ 以上保七,つつ処理するのが望ましい。

\section{$3 \cdot 2$ タンマン炉による脱硫実駼結果}

$\mathrm{CaO}$ に20 80 wt \% の $\mathrm{CaF}_{2}$ 苑含有した基本スラグ の (S)/[S] に扰よぼす $\left(\mathrm{Al}_{2} \mathrm{O}_{3}\right)$ 扰よび $\left(\mathrm{SiO}_{2}\right)$ の影響を Fig. 11 および Fig. 12 に亦す. 久ラグ中の $\left(\mathrm{Al}_{2} \mathrm{O}_{3}\right)$ および $\left(\mathrm{SiO}_{2}\right)$ が増加するとともに，(S)/[S] は単調に 低下しており，(S)/[S]の推定式は（1）式で示される.

(S) $/[\mathrm{S}]=1260-25 \times \mathrm{Al}_{2} \mathrm{O}_{3}(\mathrm{wt} \%)$

$$
-75 \times \mathrm{SiO}_{2}(\mathrm{wt} \%)
$$

H. Gruner らは6) 本失験絬果と異なり，(2) 式で示さ

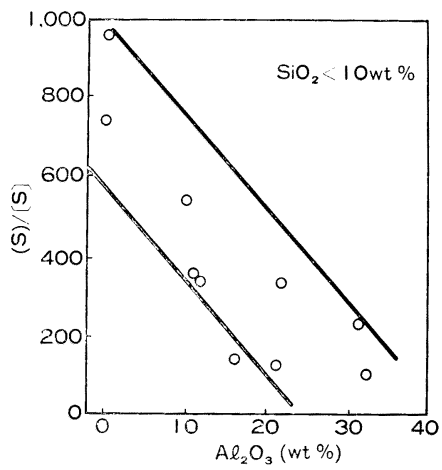

Fig. 11. Effect of $\mathrm{Al}_{2} \mathrm{O}_{3}$ content in slag on sulphur distribution $(\mathrm{S}) /[\mathrm{S}]$. (laboratory test)

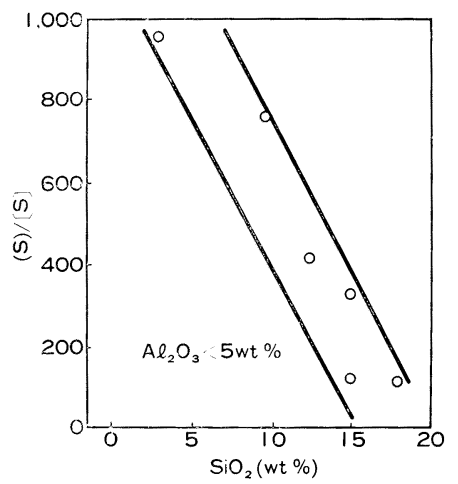

Fig. 12. Effect of $\mathrm{SiO}_{2}$ content in slag on sulphur distribution (S)/[S].

(laboratory test) 
れるスラグ指数が $0.35 \%$-1 近辺の時, 最も高い脱硫率 が得られると報告している。

$$
\text { Slag Index }=\underset{\mathrm{SiO}_{2}(\mathrm{wt} \%) \times \mathrm{Al}_{2} \mathrm{O}_{3}(\mathrm{wt} \%)}{\mathrm{CaO}(\mathrm{wt} \%)}
$$

脱硫反応は基本的には (3) 式で示されるように, 澾化し た $(\mathrm{CaO})$ が $[\mathrm{S}]$ と結合すると考えられる。

$$
(\mathrm{CaO})+[\mathrm{S}]=(\mathrm{CaS})+[\mathrm{O}] \cdots
$$

従つて，脱硫用久ラグ中の $\left(\mathrm{Al}_{2} \mathrm{O}_{3}\right)$ および $\left(\mathrm{SiO}_{2}\right)$ は, 脱硫能を低下寸る一方で $(\mathrm{CaO})$ の䐠化を促進する。こ のため, 本実験のよらにスラグ中に声化に必要な $\left(\mathrm{CaF}_{2}\right)$ が存在し，その上，反応時間が十分ある場合には， $\left(\mathrm{Al}_{2} \mathrm{O}_{3}\right)$ おょよ゙ $\left(\mathrm{SiO}_{2}\right)$ は脱硫反応を阻害するう向にだ 詐用する。一方， H. GRUNER らの垁験の場合は， $\left(\mathrm{CaF}_{2}\right)$ が少ないため, $\left(\mathrm{Al}_{2} \mathrm{O}_{3}\right)$ および $\left(\mathrm{SiO}_{2}\right)$ が $(\mathrm{CaO})$ の涬化促進に寄与している。このため，脱硫反応に対し て最適な $\left(\mathrm{Al}_{2} \mathrm{O}_{3}\right)$ および $\left(\mathrm{SiO}_{2}\right)$ 含有量が存在するも のと考えられる。

Fig. 13 に脱硫後の溶鋼 [S] におよぼす久ラグ中の $(\mathrm{CaO})$ と $\left(\mathrm{CaF}_{2}\right)$ の重量比の影響を示す。重是比が 1 対 1 の場合に最も脱硫能があることが判明したので，以 後は重量比が 1 対 1 の脱硫用スラグについて検討を行つ た。

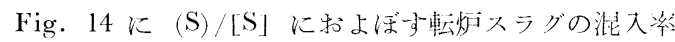
の影響を示す。転炉入ラグの影響は非常に大きく，転炉 スラグが混入していない場合に対して，混入率 $20 \%$ で (S) / [S] は約 1/4まで低下する。 これは, 転炉スラグ中 に存在する $(\mathrm{FeO}),(\mathrm{MnO})$ あるいは $\left(\mathrm{SiO}_{2}\right)$ により，

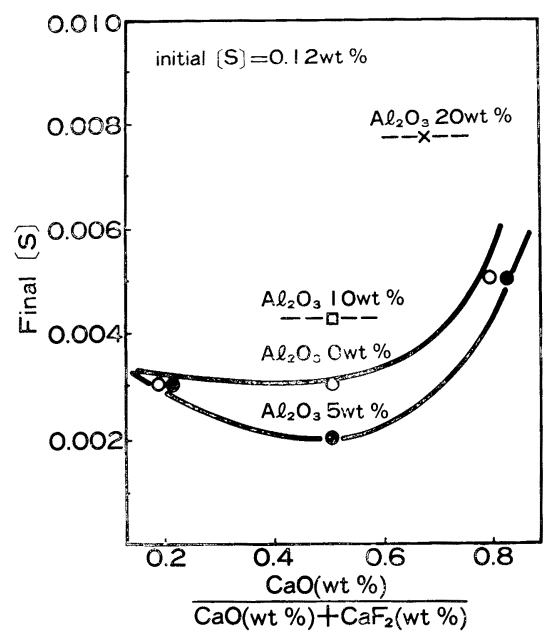

Fig. 13. Effect of slag composition $\mathrm{CaO}(\mathrm{wt} \%)$

$\mathrm{CaO}(\mathrm{wt} \%)+\mathrm{CaF}_{2}(\mathrm{wt} \%)$ on final sulphur in liquid steel.

(laboratory test)

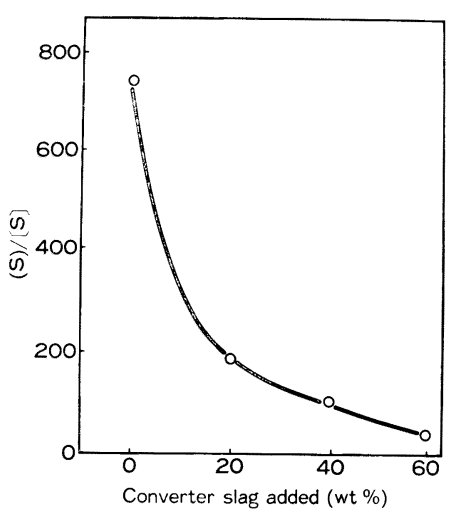

Fig. 14. Effect of converter slag addition in flux on sulphur distribution $(S) /[S]$.

(laboratory test)

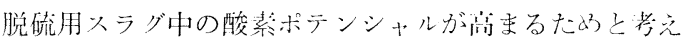
ら机る。次に，転炉火ラグ，脱陵生成物あるいは取鍋

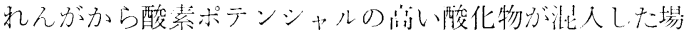

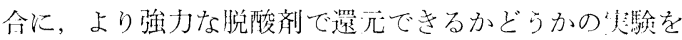
行つた。

Fig. 15 にスラグ中の $\left(\mathrm{SiO}_{2}\right)$ を $\mathrm{Ca} て ゙$ 造元しのつ脱

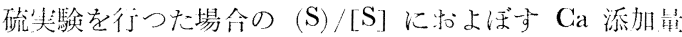

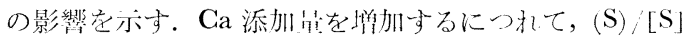
は大きくなるが， $\left(\mathrm{SiO}_{2}\right)$ の份在しない久ラグと问じ $(\mathrm{S}) /[\mathrm{S}]$ を得るためには, $\left(\mathrm{SiO}_{2}\right)$ の還元に必要な理論 㫣の約 2 倍の Ca を添加与る必要がある。

以上の実験結果より，攪排力が弱い場合でも，重㥀比 が 1 対 1 の $\mathrm{CaO}$ と $\mathrm{CaF}_{2}$ からなる脱硫火ラグを用い子 ば，溶鋼脱硫は可能であることが判明した。また，飐操 策の場合には，スラグ中の $(\mathrm{FeO}),(\mathrm{MnO})$ あるいは $\left(\mathrm{SiO}_{2}\right)$ を極力低下させるために，転炉火ラグの完全な カットと, 出鋼時の溶鋼の強脱酸を行う必装があると考

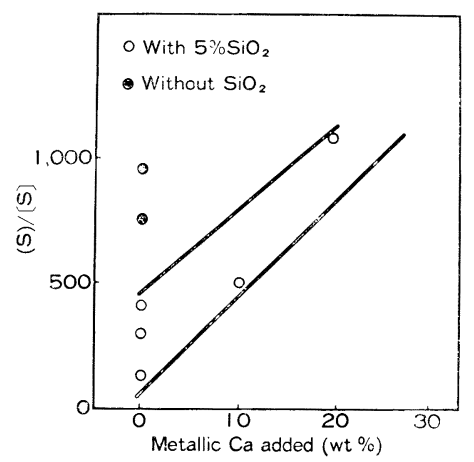

Fig. 15. Effect of metallic Ca addition in flux on sulphur distribution (S) / [S].

(laboratory test) 


\section{兊られる。}

\section{3 実機 RH における脱硫実験結果}

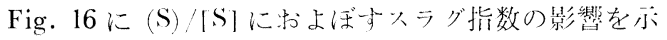
与、 久ラグ指数の增加とともに，(S)/[S]は大きくな り、 $\mathrm{CaO}-\mathrm{Al}_{2} \mathrm{O}_{3}-\mathrm{SiO}_{2}$ 系の脱硫用以ラグの場命6)のよ

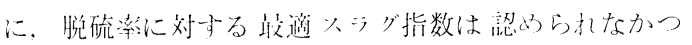

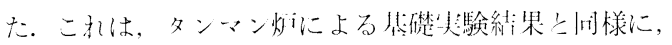
$\mathrm{CaO}-\mathrm{CaF}_{2}$ 系火ラグの埸介は， $\left(\mathrm{CaF}_{2}\right)$ により 以ラグの 融占が十分に低くなつているため, $\left(\mathrm{Al}_{2} \mathrm{O}_{3}\right)$ 求よび

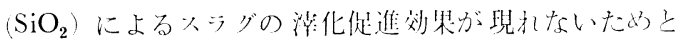
考它战る。

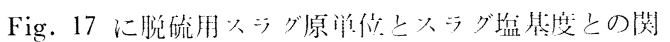
係を示与。取鍋耐火物がジルコン質れんがの場合, 脱硫 用スラグの原単位が增加するとももに，火ラグ壏基度は

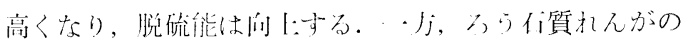

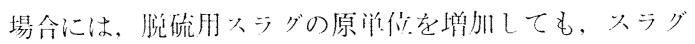

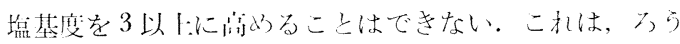

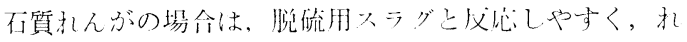

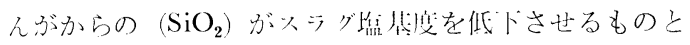

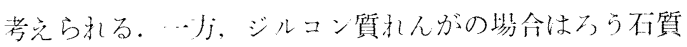

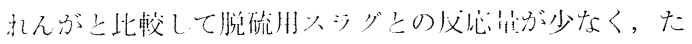

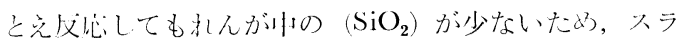

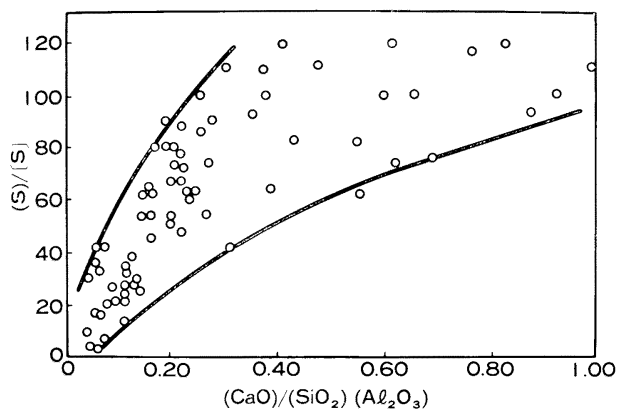

Fig. 16. Relation between $\underset{\mathrm{SiO}_{2} \cdot \mathrm{Al}_{2} \mathrm{O}_{3}}{\mathrm{CaO}}$ and $(S) /[S]$.

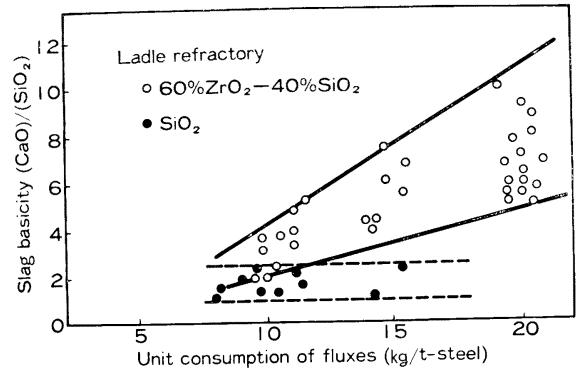

Fig. 17. Relation between unit consumption of fluxes and slag basicity $(\mathrm{CaO}) /\left(\mathrm{SiO}_{2}\right)$.
グ塩基度を高く保てるものと考えられる。

Fig. 18 に(S)/[S|におよぼす大ラグ中の (T.Fe) と

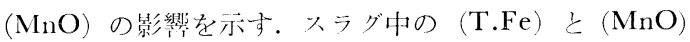
の影響は大きく，脱硫効䜌を高めるためには，(T.Fe) と $(\mathrm{MnO}$ ( ) を下げる必装がある。スラグ中の酸素ポテン

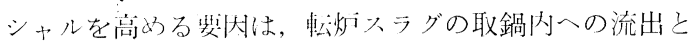
Mnなどの合金添加により生成した脱酸牛成物が考えら 机る。本ブロ七久では，上䛉要内除去するため，出鋼 時の Al による先行強脱酸および 2 鍋出鋼による転炉火 ラグのカットを这施し， スラグ中の ( T.Fe) と $(\mathrm{MnO})$ を低位に安定させた。

Fig. 19 に出鋼から製占束での溶鋼成分の変化を示す. 溶鋼中の [S] は RH.OB-FI) 処理による昗温時に若干 の復硫を生:じるが，こ扎早温時に生成する $\mathrm{Al}_{2} \mathrm{O}_{3}$ に より，脱硫用火ラグの脱硫能が低下するためである。そ の後, 脱硫为火ラグを $\mathrm{RH}$ 具空槽内一添加することによ り，脱硫が進行し製出 [S] は $10 \mathrm{ppm}$ まで低下してい る. [T.O]については， $\mathrm{O}_{2}$ ガス吹き这みを行つている $\mathrm{RH} \cdot \mathrm{OB}-\mathrm{FD}$ 処理時にも低下しており，鋼中の [Al] お よび $\mathrm{O}_{2}$ ガ久欣き远久速度を調整与ることにより，[T.O ] の上㘶を防止しつつ外湍が可能である。亦た，Fig. 9 に $R H$ 具空槽内一の脱硫用久ラグ添加の有無による $V_{E}$ で

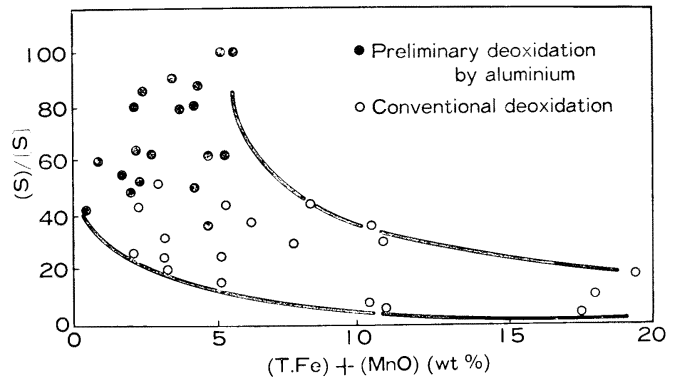

Fig. 18. Relation of the oxygen potential of flux and the distribution coefficient $(\mathrm{S}) /[\mathrm{S}]$.

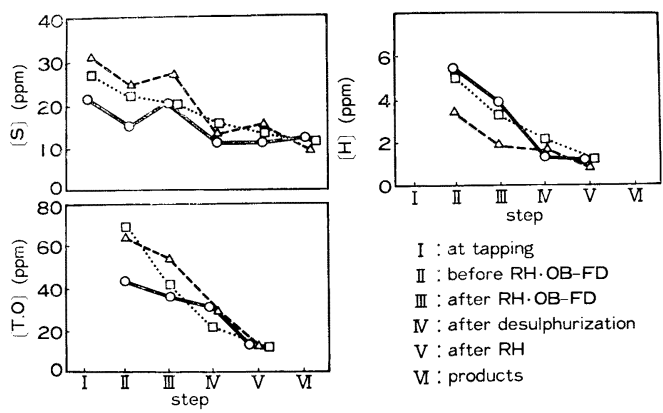

Fig. 19. Changes of chemical compositions in the $\mathrm{VOF}$ process. 

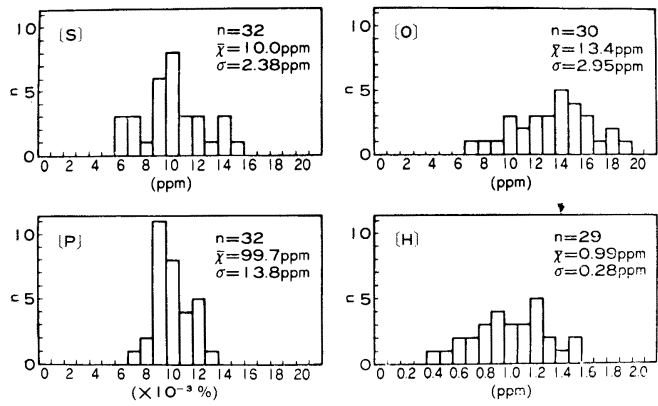

Fig. 20. Chemical composition of molten steel.

の「T.O を比較したが，脱硫用火ラグを添加すること により，通常 $\mathrm{RH}$ と比較して約 $10 \mathrm{ppm}$ は低トさせる ことが可能となつた。これは後述するよらに，性した $\mathrm{Al}_{2} \mathrm{O}_{3}$ が脱硫用火ラグと反心し浮、分離されるためと考 えられる。また, 従来のハウダーインジェクションによ

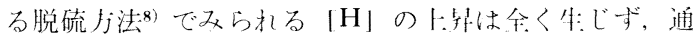
常の RH の脱水素機能は十分に牛かさ机ている.

Fig. 20 にVOFプロ七火により製造された製品の成 分分有を走亦. 現状の $\mathrm{RH}$ 機能に加熱機能亡脱硫機能 を付加することにより，不純物九䒺の $\mathrm{S} ， \mathrm{P}, \mathrm{O}, \mathrm{H}$ を ともに低下でき，清浄性の良い製品の製造が叮能となつ た.

\section{4. 考察}

\subsection{RH.OB-FD 処理時の温度推移の推定}

[C] : $0.15 \sim 0.35 \mathrm{wt} \%, \quad[\mathrm{Si}]: 0.15 \sim 0.35 \mathrm{wt} \%$, $[\mathrm{Mn}]: 1.00 \sim 1.60 \mathrm{wt} \%,[\mathrm{Al}]: 0 \sim 0.150 \mathrm{wt} \%$ の浴鋼 $\mathrm{W}(\mathrm{t})$ に $\mathrm{O}_{2}$ ガ火を $\mathrm{F}_{\mathrm{O}_{2}}\left(\mathrm{Nm}^{3} / \mathrm{h}\right)$ の速度で收き込及，

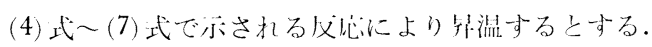

$$
\mathrm{Al}+3 / 4 \mathrm{O}_{2}=1 / 2 \mathrm{Al}_{2} \mathrm{O}_{3}
$$$$
J H_{\mathrm{Al}}=-200200 \mathrm{kcal} / \mathrm{kmol}
$$

$\mathrm{Si}+\mathrm{O}_{2}=\mathrm{SiO}_{2} \quad J H_{\mathrm{Si}}=-209550 \mathrm{kcal} / \mathrm{kmol} \cdots(5)$

$\mathrm{Mn}+1 / 2 \mathrm{O}_{2}=\mathrm{MnO}$

$$
\lrcorner H_{\mathrm{Mn}}=-92050 \mathrm{kcal} / \mathrm{kmol}
$$

$\mathrm{C}+55 / 100 \mathrm{O}_{2}=90 / 100 \mathrm{CO}+10 / 100 \mathrm{CO}_{2}$

$$
\lrcorner H_{\mathrm{C}}-70278 \mathrm{kcal} / \mathrm{kmol}
$$

なお，(7)式は後の莎算簡略化するため， $\mathrm{CO} と \mathrm{CO}_{2}$ 濃度の比は排ガ久分析結果より，9対 1 で定と伐定し， (8)式と (9) 式より求ぬた。

$$
\begin{aligned}
& \mathrm{C}+1 / 2 \mathrm{O}_{2}=\mathrm{CO} \\
& \lrcorner H_{\mathrm{C}}^{\prime}=-67636 \mathrm{kcal} / \mathrm{kmol} \\
& \mathrm{CO}+1 / 2 \mathrm{O}_{2}=\mathrm{CO}_{2} \\
& \lrcorner H_{\mathrm{CO}}^{\prime}=-26416 \mathrm{kcal} / \mathrm{kmol} .
\end{aligned}
$$

従つて, $\mathrm{O}_{2}$ ガス供給昷に対して各无素により消費され る制合は (10)式でホされる。

$$
X_{\mathrm{i}}=1.344 \times 10^{6} m_{\mathrm{i}} \begin{aligned}
& \lrcorner C_{\mathrm{i}} W \\
& M_{\mathrm{i}} F_{\mathrm{O}_{2}}
\end{aligned}
$$

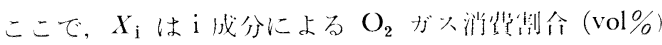
$m_{\mathrm{i}}$ は $\mathrm{i}$ 成分の凌化に必装な $\mathrm{O}_{2}$ ガ久のモん比 $(-)$

$J C_{\mathrm{i}}$ は $\mathrm{i}$ 成分の娍少速度: ( $\left.\mathrm{wt} \% / \mathrm{min}\right)$

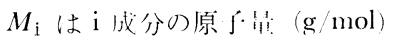

Fig. 4 Fig. 7 加 $|\mathrm{Al}|$ の関数上にて」C 老求心,

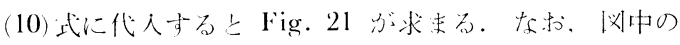
来仅仙酸素は $\mathrm{O}_{2}$ ガ

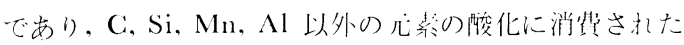

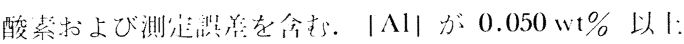
になると $X_{\mathrm{c}}$ は总激に娍少し， $X_{\mathrm{A} 1}$ は增打する。亦た $X_{\mathrm{Mn}}$ および $X_{\mathrm{Si}}$ は 10〜20 vol\%であり、|Al|の影響 は小さい.

次に RH.OB-FI) 処理により|Al|が $x_{1}$ から $x_{2}$ 䒠

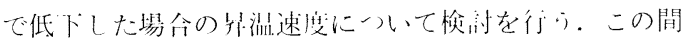

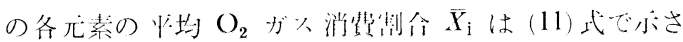
孔る。

$$
X_{\mathrm{i}}=\int_{x_{2}}^{x_{1}} X_{\mathrm{i}} d x /\left(x_{1}-x_{2}\right)
$$

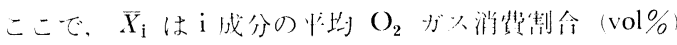
従一て， $x_{1}$ から $x_{2}$ まで $|A 1|$ が低卜求るのに必要な

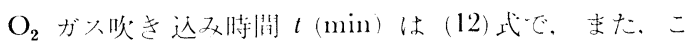
の間の全発熱粘Q $Q(\mathrm{cal})$ は（13）式でホされる.

$$
t=1.344 \times 10^{6} W\left(x_{1} \cdots x_{2}\right) \begin{array}{ccc}
m_{\mathrm{Al}} & 1 & 1 \\
M_{\Lambda 1} & F_{\mathrm{O}_{2}} & X_{\mathrm{Al}}
\end{array}
$$

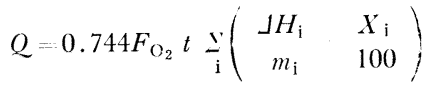

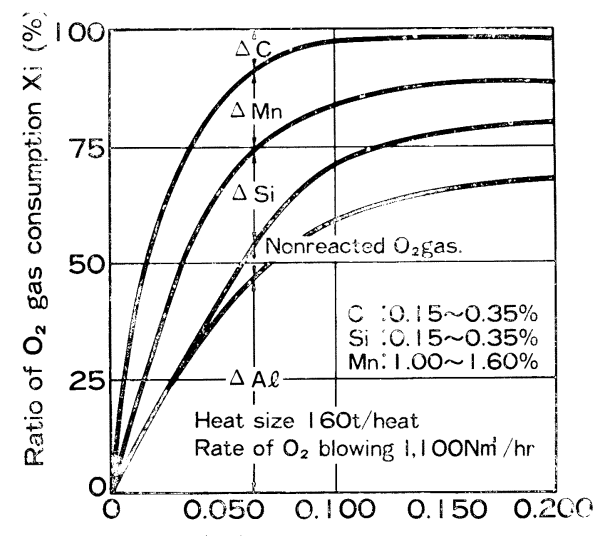

(Al] in lipuid steel (wi\%)

Fig. 21. Relation between ratio of $\mathrm{O}_{2}$ gas consumption for combustion of $\mathrm{C}, \mathrm{Mn}, \mathrm{Si}$ and $\mathrm{Al}$ in liquid steel during oxygen blowing. 
こニー゙,JH

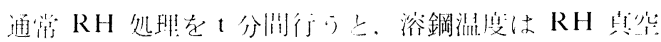
槽尔よび取鋿などにより冷却され，浴鋼滥度はFig. 3

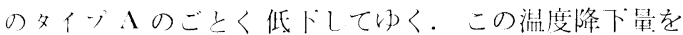
$J T_{0}\left({ }^{\circ} \mathrm{C}\right)$ 上小る。束た， RH.OB-FI) 処理前後の溶鋼

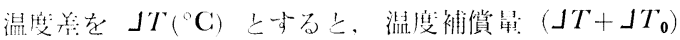
は（14）式で小される。

$$
\lrcorner T+\lrcorner T_{\mathbf{0}} \cdots C_{\mathrm{p}} W \times 10^{6}
$$

こニで， $C_{\mathrm{p}}$ は浴鋼の比熟 $\left(\mathrm{cal} /{ }^{\circ} \mathrm{C} \cdot \mathrm{g}\right)$

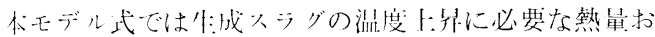

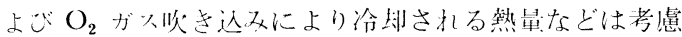
していないので，连際にはこれらを補可する必要がある。 温度補償早! $\left(」 T+J T_{\mathbf{0}}\right)$ の Fig. 22 に示す。この洲よ引、叶算による温度補償帠の

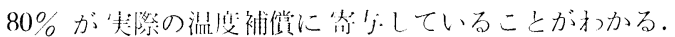

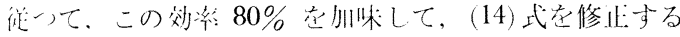

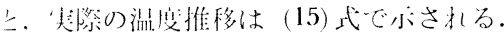

$$
\begin{gathered}
0.8 Q \\
C_{\mathrm{p}} \cdot W \times 10^{6} \quad T_{0}
\end{gathered}
$$

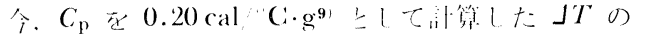

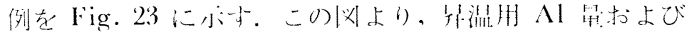

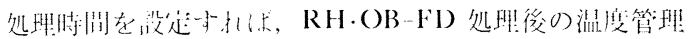
加叮能上なる。

\section{$4 \cdot 2 \mathrm{Al}$ の優先酸化におよぼす環流速度の影響}

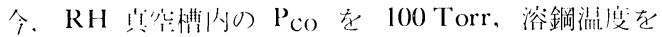
$1650 \mathrm{C}$ 上佊定し。 $0.050 \mathrm{wt} \% \mathrm{Al} ， 1.50 \mathrm{wt} \% \mathrm{M}_{11}, 0.10$

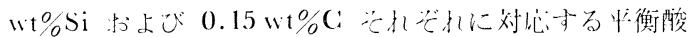

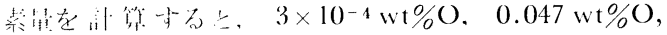
$0.025 \mathrm{wt} \% \mathrm{O}$ および $0.002 \mathrm{wt} \% \mathrm{O}$ 上なる10). 徒つて,

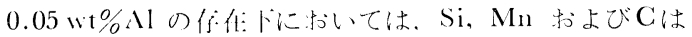
腰化しないはナ゙であるが，Fig. 21 にみられるよらに，

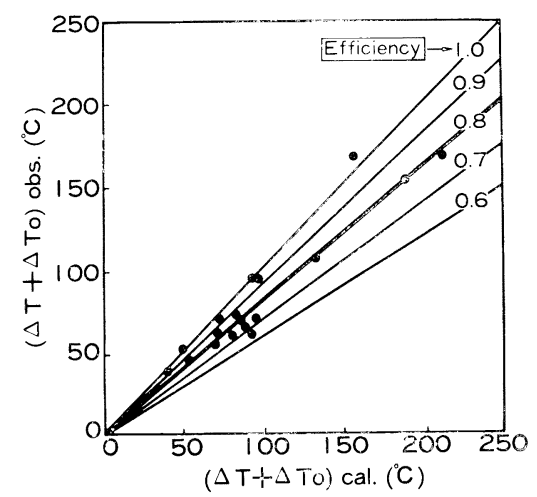

Fig. 22. Comparison of temperature calculated and temperature observed for rising temperature (\lrcorner $\left.T-\lrcorner T_{0}\right)$ in the $\mathrm{RH} \cdot \mathrm{OB}-\mathrm{FD}$.

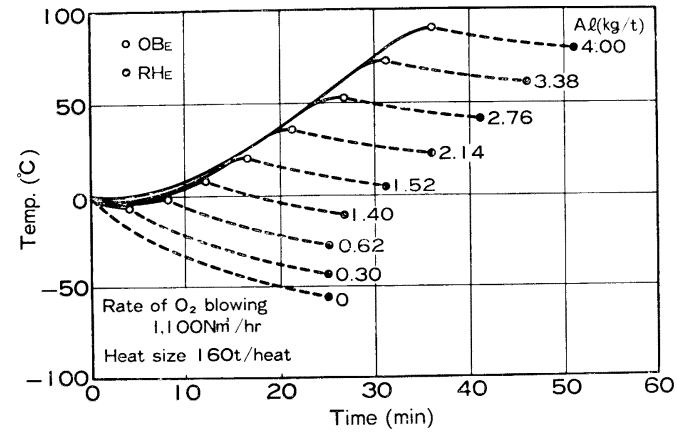

Fig. 23. Behavior of temperature in the $\mathrm{RH} \cdot \mathrm{OB}-\mathrm{FD}$.

'进際は $0.05 \mathrm{wt} \% \Lambda 1$ の存在ドでも, 若干の脱轨, 脱ーンン ガンおよび脱炭は拉じている.

ここで，酸素が火吹き込み位䈯で環流溶鋼中の $\mathrm{Al}$ が 完全に訟化された後に，Si，Mn およびCが酸化すると 考えると， $X_{\mathrm{Al}}$ は (16) 式で小される。ここで， $Y(\mathrm{t} /$ min）は浴鋼の環流速度である。

$$
X_{\Lambda 1}-3.60 \times 10^{2} \stackrel{[\mathrm{Al}] \cdot Y}{F_{\mathrm{O}_{2}}}
$$

(16)式から算出した $X_{\mathrm{A} 1}$ を细測伯とももに Fig. 24 に 亦与. $0.050 \mathrm{wt} \% \mathrm{Al}$ までは, ’測佔は環流速度 $25 \mathrm{t} / \mathrm{min}$

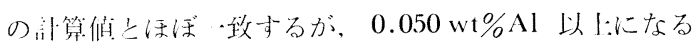
と。尖測值は叶算䧸より，小さくなる。このことより， $0.050 \mathrm{wt} \% \mathrm{Al}$ 以!では $\mathrm{Al}$ 你在ドで $\mathrm{Si}, \mathrm{Mn}$ 抢よびC

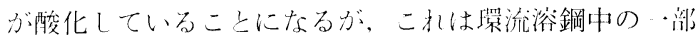

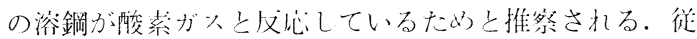

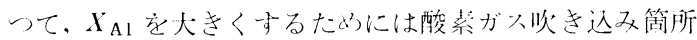

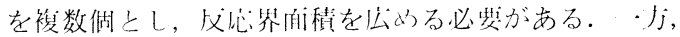
$0.050 \mathrm{wt} \% \mathrm{Al}$ 以卜では， $\mathrm{Al}$ の供給律速となり，過剩の 酸榇ガ火が $\mathrm{C}$ と文仙していると考えら机る。従つて， [Al」が低いとこんで $X_{\mathrm{Al}}$ を大きくするには噮流を速め

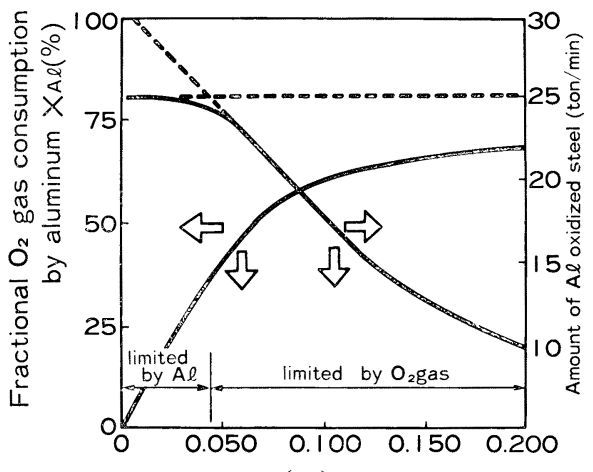

(Al) (wt \%)

Fig. 24. Effect of $[\mathrm{Al}]$ in molten steel on amount of $\mathrm{Al}$ oxidized steel in the $\mathrm{RH} \cdot \mathrm{OB}-\mathrm{FD}$. 


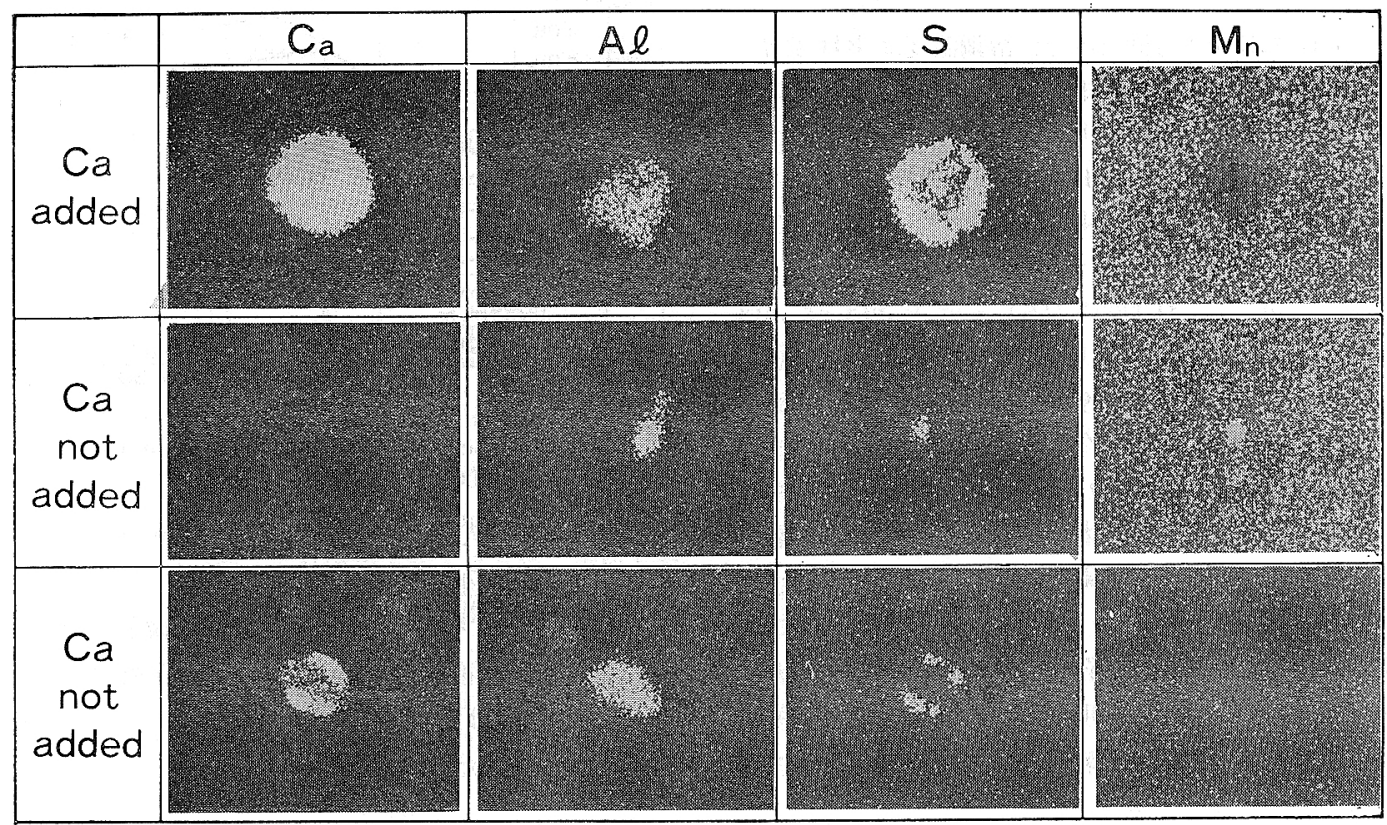

Photo. 1. EPMA images of typical inclusions.

$\overline{50 \mu}$

るのが望をしい。

\section{3 脱硫・脱酸に対する脱硫用スラグの効果}

Photo. 1 に鋼塊中に存在した代表的な介在物の EPMA の面分析結果を示す. VOF 処理した後, 注入時

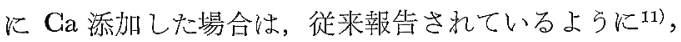
カルシウムアルミネイトの外周部に硫化カルシウムが凝 集した介在物が主体となつている。 また， Ca 添加をし ない場合でも，カルシウムアルミネイトが主体の介在物 であるが，Ca 添加した場合と比較して介在物径は小さ くなつている. 後者のカルシウムアルミネイトは, 昇温

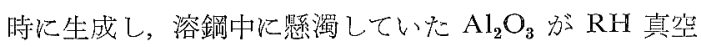
槽から添加した脱硫用スラグと反応し生成したもので, 生成から注入禹での時間が比較的に長いために，大型の 介在物は浮上し，微細な介在物だ汁が残存したるの之考 えられる. 一方, 前者のカルンウムアルミネイトは, 注 入時の $\mathrm{Ca}$ 添加により生成したものであり，浮上時間が 比較的短いために，大型の介在物怔残存したものと考光 られる。このように，RH真空槽内への脱硫用スラグの 添加は，脱硫ばかりでなく，介在物の浮上促進による [T.O]の低下に寄与して路り, その結果として, Fig. 9 に示したように, VOF 処理溶鋼の [T.O] が低下す るものと考光ら机る。

また, Photo. 1 にみられるように Ca 添加を行つて

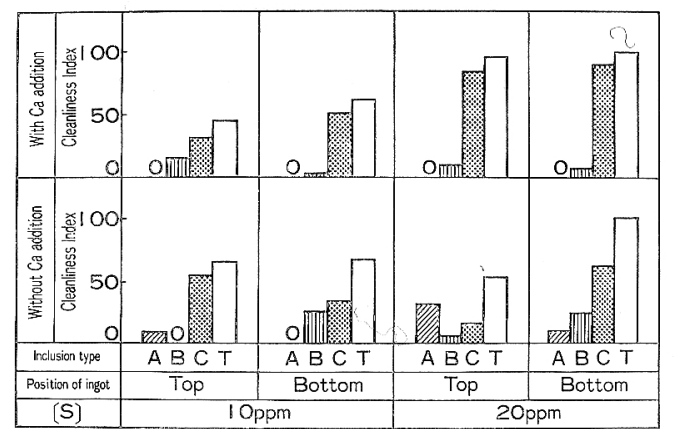

Fig. 25. Effect of sulphur content and metallic calcium addition on cleanliness of steel.

いない場合でも，脱硫用スラグにより［S］の汪とんど は硫化カルシウムとして固定されている坊，溶鋼の濃化 が生じる鋼塊頡部側では微細な硫化マンガンが生成して いる．Fig. 25 に厚板製品の清浄度を示した。Ca 添加 を行わない場合でも，溶鎆 [S] t $10 \mathrm{ppm}$ をで減少さ せることにより，A系介在物は減少与るが，皆無にする ことは困難である。一西， $\mathrm{Ca}$ 添加写行つた場合は，A 系介在物は皆無となるが，G系介在物が㙞加し，全体の 清浄度性悪くなる傾向心方る。従つて，全体の清浄性它 良くするためには，[S] を $10 \mathrm{ppm}$ 程度の低硫鋼にした

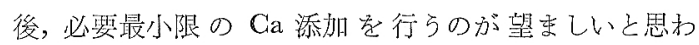


れる。

\section{5. 結}

\section{言}

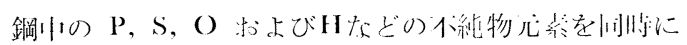

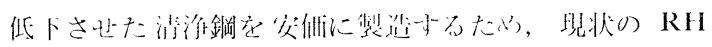

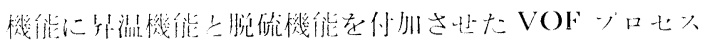

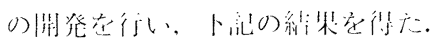

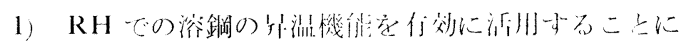

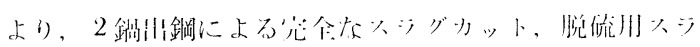

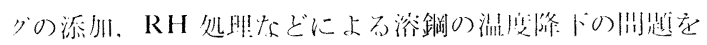

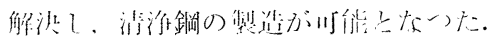

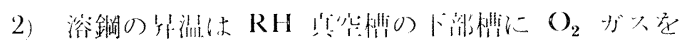

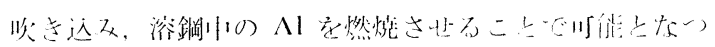

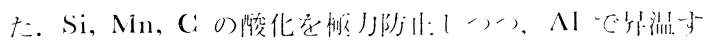

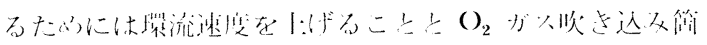

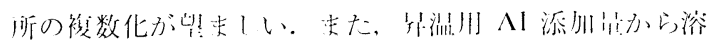

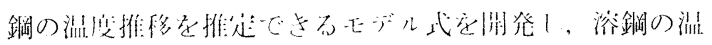

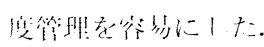

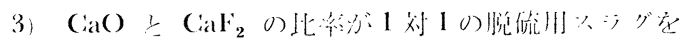

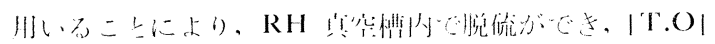

も低浐に文定させることが可能となつた。

\section{交献}

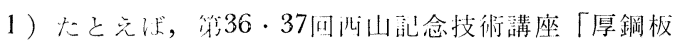

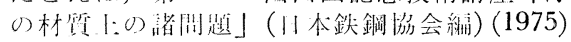

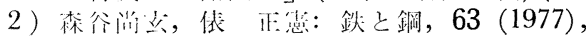
p. 2070

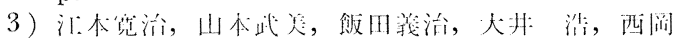

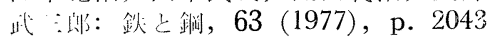

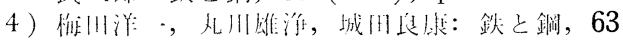
(1977), p. 2054

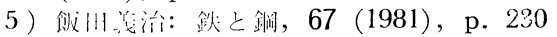

$6) H$. Gruner, $F$. Bardenheuer, $H-W$. RommerswinкEL, and $H$. SChulte: Stahl Eisen, 96 (1976), p. 960

7 ) G. J. Kor and F. D. Richardson: Trans. Met. Soc. AIME, 245 (1965), p. 319

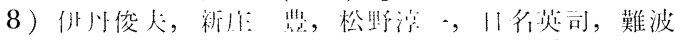

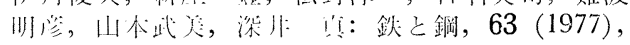
$\$ 586$

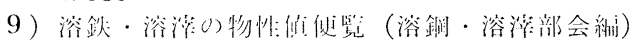
(1972), p. 183 [11林鈥銅茄公]

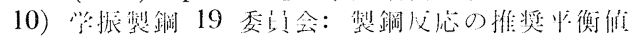
(1968) 「11 仜 T: 彩新聞社:」

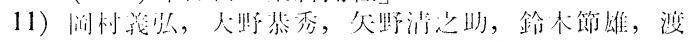
沉凹地：鉄之铜，65 (1979)，A33 